\title{
Vine balance: a study case in Carménère grapevines
}

\author{
Claudio Fredes ${ }^{1}$, Yerko Moreno ${ }^{2}$, Samuel Ortega ${ }^{2}$, and Eduardo Von \\ Bennewitz ${ }^{1}$ \\ ${ }^{1}$ Escuela de Agronomía, Universidad Católica del Maule, Chile. Casilla 7D, Curicó. \\ ${ }^{2}$ Escuela de Agronomía, Universidad de Talca, Casilla 747, Talca, Chile.
}

\begin{abstract}
C. Fredes, Y. Moreno, S. Ortega, and E. Von Bennewitz. 2010. Vine balance: a study case in Carménère grapevines. Cien. Inv. Agr. 37(1):143-150. Vitis vinifera cv. Carménère is a vigorous variety of grapevine that requires high temperatures and luminosity for achieving optimal phenolic maturity and herbal aromas, which has been reported to significantly delay harvest in Chile. This research was developed under the hypothesis that canopy management, vigor and crop load could modify the productive and vegetative relationships for obtaining early or late ripening and achieving vine balance. The aim of this study was to determine the vine balance and the time of ripeness for Carménère grapevines. Different vigor and canopy managements were evaluated. The study was conducted in the Central Valley of Chile during the 2007 to 2008 season with own-rooted Carménère vines trained to a four-cane vertical shoot position (VSP) located on high growth potential soil. The ripeness was delayed with high vigor and high crop load. In this growing condition, an early ripeness was reached with spur pruning, low vigor and by cluster thinning. In addition, the appropriate vine balance was only obtained in vines with low vigor and 50\% cluster thinning. Together, these data demonstrate the vine balance of Carménère under these management conditions.
\end{abstract}

Key words: Canopy management, cluster thinning, grape ripeness, pruning, vine balance, Vitis vinifera.

\section{Introduction}

Vine balance implies constant quality and on time yield. The proper grape ripeness can be reached when a vineyard has a balanced yield (Howell, 2001) and is harvested at the right time. Several strategies for reporting and controlling vine balance have been proposed (Hunter and Archer, 2000; Smart and Robinson, 1991). An accepted definition of this equilibrium between

Received 25 May 2009. Accepted 24 August 2009. Corresponding author: cfredes@ucm.cl crop load and vegetative growth is the leaf area required for maximizing the yield and ripeness. This equilibrium has been reported to range from $7 \mathrm{~cm}^{2} \mathrm{~g}^{-1}$ to $14 \mathrm{~cm}^{2} \mathrm{~g}^{-1}$ (Howell, 2001) and between $8 \mathrm{~cm}^{2} \mathrm{~g}^{-1}$ and $12 \mathrm{~cm}^{2} \mathrm{~g}^{-1}$ (Kliewer and Dokoozlian, 2005). Furthermore, Smart and Robinson (1991) indicated that the balanced Ravaz index (fruit yield/pruning weight) is between five and ten. The traditional definition of vine balance was the minimum leaf area required to adequately ripen the fruit in terms of accumulation of soluble solids (Winkler, 1958).

The vine balance implies a constant quality and yield (Smart and Robinson, 1991), and depends on crop load (Tassie and Freeman, 1992), accu- 
mulation of soluble solids at harvest (Winkler, 1958), cultivars (Gil and Pszczolkowski, 2007; Kliewer and Dokoozlian, 2005), light intensity under the canopy (Howell, 2001), growth potential of soil (Intrieri et al., 2001), climate (Kliewer and Weaver, 1971), and training system (Kliewer and Dokoozlian, 2005).

The canopy microclimate conditions can be measured by a vineyard scorecard, leaf layer number and percentage of inside clusters (Smart and Robinson, 1991). The canopy manipulations that decrease the leaf area/fruit weight ratios and low vigor vines improve the microclimate conditions that increase the cluster illumination and decrease the relative humidity (Smart, 1985). The timing of canopy management is crucial to modify grape compositions (Van Schalkwyk et al., 1995) and to reduce management cost (Hunter, 2000).

Chilean vineyards habitually present an excessive vegetative growth (Fredes, 2007) allowing shaped clusters as well as poor induction and development of buds. This unbalance causes low quality wine potential (Smart and Robinson, 1991) and negatively modifies the fruit composition (Zoecklein, 2001). In these cases, canopy management is the alternative for improving fruit composition (Hunter, 2000, Edson et al., 1995) by practices, such as pruning, cluster thinning, leaf removal and shoot removal. Carménère grapevines are a vigorous and late cultivar with low basal bud fertility that should be cane pruned (Gil and Pszczolkowski, 2007) and, often, require extra leaf removal in the summer to decrease herbal aromas in wine (Belancic and Agosin, 2007). This cultivar contains high levels of seed monomers, such as epicatechin gallate (Mattivi et al., 2009) and, therefore, requires more time for reaching proper phenolic maturity. These data suggest that the vine balance of the Carménère grapevine cultivar is higher than the accepted definition of $14 \mathrm{~cm}^{2} \mathrm{~g}^{-1}$ (Kliewer and Dokoozlian, 2005).

The phenolic maturity is used as an index to determine harvest date, and it has been utilized to significantly delay harvest in Chile, which favors the development of molds that can affect must and wine qualities (Pszczolkowski et al., 2001). A more restricted leaf area/fruit weight ratio delays the ripeness (Howell, 2001; Edson et al., 1995). Nevertheless, some management practices, such as lateral shoot thinning and leaf removal, neither delay nor advance the fruit ripeness (Vasconcelos and Castagnoli, 2000; Hunter, 2000).

This study compares different canopy managements with vine balance indexes for selecting the better management strategies for achieving fruit ripeness. The aim of this study was to determine the vine balance and the time of ripeness for Carménère grapevines under different levels of vigor, leaf removal, lateral shoot removal, cluster thinning and length of pruning.

\section{Material and Methods}

This study was conducted in the Curicó Valley (34 $52^{\prime}$ South Latitude, $71^{\circ} 11^{\prime}$ West Longitude) during the 2007-2008 season with own-rooted Carménère vines. The vines were planted in 1997 and trained to four-cane vertical shoot position (VSP) with a vine spacing of $1 \mathrm{~m}$ and a row spacing of $2 \mathrm{~m}$. The annual crop yield has been $9-11 \mathrm{t} \mathrm{ha}^{-1}$. Vines were balance pruned to 30 buds per $\mathrm{kg}$ of pruning weight. The vines were subjected to the following: water shoot removal before flowering, partial leaf removal at veraison and total leaf removal at $21^{\circ} \mathrm{Bx}$.

The climate is classified as Mediterranean (1.658 degree-days and $1.234 \mathrm{~h}<7^{\circ} \mathrm{C}$ ), and the soil is 
alluvial with a phreatic level depth at $2 \mathrm{~m}$. The site has high potential of growth, and the vineyard studied was certified as organic in 2003.

\section{Design and statistical analysis}

Three factorial experiments were analyzed involving two factors with two or three levels in each one. Each interaction had six replicates containing one plant. The experimental conditions were as follows: 1) combination of high, middle and low vigor vines (pruning weight per meter and trunk diameter, respectively, for the following: high $=850-950 \mathrm{~g} \mathrm{~m}^{-1}$, less than 5 $\mathrm{cm}$; middle $=650-750 \mathrm{~g} \mathrm{~m}^{-1}, 5 \mathrm{~cm}$ to $6 \mathrm{~cm}$; and low $=350-450 \mathrm{~g} \mathrm{~m}^{-1}, 6 \mathrm{~cm}$ to $7 \mathrm{~cm}$ ) and cluster thinning ( $0 \%$ and $50 \%)$; 2 ) combination of $100 \%$ leaf removal (with and without leaves on cluster zone) and lateral shoot thinning (basal on cluster zone or complete shoot); and 3) combination of pruning length (spur and cane) and lateral shoot thinning (basal, complete and without). The handling was done biweekly on sun exposure side, starting at veraison until harvest, and the harvest was on April 7, 2008.

Factorial analysis of the variance was completed with the aid of SPSS $\AA$ version 17 , and the means of each interaction combination were compared by the Tukey test $(\mathrm{p}<0.05)$.

\section{Graphic method}

Two graphs were developed to demonstrate vine balance using vines in a wide range of leaf area/crop weight ratios according to methodology used by Kliewer and Dookozlian (2005). In brief, the following graphs were presented: 1) An inverse relationship between the Ravaz index (fruit weight/cane weight) and the leaf area/fruit weight ratio with the vines displayed in the graphs according their vine balance level and 2) An asymptotic relation between leaf/ fruit weight and soluble solids.

\section{Measurements and analysis}

Leaf areas were indirectly measured at harvest time by measuring the blade weight with the correlation model development as follows: $\mathrm{Y}=$ 47.716X -1580 , where $\mathrm{R}^{2}=0.99, \mathrm{X}=$ blade weight and $\mathrm{Y}=$ leaf area (Fredes, 2007). The leaf area index was determined by calculating the surface of leaves in relation to the ground directly below the plant, and it was estimated to be $0.9 \mathrm{~m}$ per vine. The point quadrants, vineyard scorecards, yield/pruning weight ratios (Ravaz index) and leaf area/crop load weight ratios were determined according to Smart and Robinson (1991). The grape phenolic composition (skin phenols and extractable anthocyanins) was determined by the Glories method (Saint-Cricq et al., 1998) in Centro Tecnológico de la Vid y el Vino, Universidad de Talca, Chile.

\section{Results and discussion}

\section{Outside vine balance}

The leaf area/crop weight ratios and Ravaz indexes were higher in most cases compared to values proposed by Howell (2001), Smart and Robinson (1991) and Kliewer and Dokoozlian (2005) (7 - $14 \mathrm{~cm}^{2} \mathrm{~g}^{-1}$, Table 1).

In Figure 1, the standard vine balance was compared with Carménère vine balance by a rela- 
Table 1. Effects of canopy management on vine balance indicators in Vitis vinifera cv. Carménère.

\begin{tabular}{|c|c|c|c|c|c|c|c|c|}
\hline \multirow[b]{2}{*}{ Treatments } & \multicolumn{8}{|c|}{ Indicators of vine balance } \\
\hline & $\begin{array}{l}\text { Soluble } \\
\text { solids } \\
{ }^{\circ} \text { Brix }\end{array}$ & $\begin{array}{l}\text { Leaf Area } \\
\text { Index }\end{array}$ & $\begin{array}{l}\text { Pruning } \\
\text { weight } \\
\text { / meter } \\
\mathrm{g} \mathrm{m}^{-1}\end{array}$ & $\begin{array}{l}\text { Ravaz } \\
\text { Index }\end{array}$ & $\begin{array}{l}\text { Leaf area } \\
\text { / crop } \\
\text { weight } \\
\mathrm{cm}^{2} \mathrm{~g}^{-1}\end{array}$ & $\begin{array}{l}\text { Vineyard } \\
\text { scorecard }\end{array}$ & $\begin{array}{l}\text { Leaf layer } \\
\text { number }\end{array}$ & $\begin{array}{l}\text { Inside } \\
\text { cluster \% }\end{array}$ \\
\hline \multicolumn{9}{|c|}{ Experiment 1: Pruning weight $\mathrm{x}$ cluster thinning ${ }^{1}$} \\
\hline \multicolumn{9}{|l|}{ Vigor (V) } \\
\hline Low & $23.4 \mathrm{a}$ & $3.89 \mathrm{c}$ & $433 \mathrm{c}$ & $5.5 \mathrm{a}$ & $12.1 \mathrm{~b}$ & $65 \mathrm{a}$ & 2.8 & $25.3 \mathrm{~b}$ \\
\hline Middle & $21.4 \mathrm{~b}$ & 55.00 & $700 \mathrm{~b}$ & $3.9 \mathrm{ab}$ & $13.5 \mathrm{~b}$ & $53 \mathrm{~b}$ & 3.0 & $54.4 \mathrm{a}$ \\
\hline High & $21.4 \mathrm{~b}$ & $10.31 \mathrm{a}$ & $953 \mathrm{a}$ & $3.7 \mathrm{~b}$ & $20.9 \mathrm{a}$ & $46 \mathrm{~b}$ & 3.5 & $53.0 \mathrm{a}$ \\
\hline \multicolumn{9}{|c|}{ Cluster thinning $(\mathrm{CT}), \%$} \\
\hline 0 & $21.6 \mathrm{~b}$ & 6.00 & 727 & $5.1 \mathrm{a}$ & $11.3 \mathrm{~b}$ & 54 & 3.1 & $52.4 \mathrm{a}$ \\
\hline 50 & $22.4 \mathrm{a}$ & 6.83 & 667 & $3.6 \mathrm{~b}$ & $19.8 \mathrm{a}$ & 55 & 3.1 & $34.3 \mathrm{~b}$ \\
\hline Interaction, $\mathrm{VxCT}$ & Sign. & ns & ns & ns & ns & ns & ns & Sign. \\
\hline \multicolumn{9}{|c|}{ Experiment 2: Leaf removal $x$ lateral shoot thinning ${ }^{1}$} \\
\hline \multicolumn{9}{|l|}{ Leaf removal (LR) } \\
\hline No & 22.1 & 6.22 & 815 & 2.5 & $20.3 \mathrm{a}$ & $58 \mathrm{~b}$ & 2.3 & $65.4 \mathrm{a}$ \\
\hline Yes & 21.9 & 5.57 & 873 & 2.7 & $17.3 \mathrm{~b}$ & $69 \mathrm{a}$ & 1.9 & $37.1 \mathrm{~b}$ \\
\hline \multicolumn{9}{|c|}{ Lateral shoot thinning (LSR) } \\
\hline Total & 21.7 & 5.79 & 873 & 2.64 & $21.1 \mathrm{a}$ & $62 \mathrm{a}$ & 2.1 & 50.7 \\
\hline Basal & 22.3 & 6.00 & 696 & 2.51 & $20.3 \mathrm{a}$ & $58 \mathrm{~b}$ & 2.0 & 51.8 \\
\hline Interaction, LRxLSR & ns & ns & ns & ns & $\mathrm{ns}$ & $\mathrm{ns}$ & ns & ns \\
\hline
\end{tabular}

Experiment 3: Length of pruning $\mathrm{x}$ lateral shoot removal ${ }^{1}$

Length of pruning (LP)

$\begin{array}{lllllllll}\text { Cane } & 21.2 \mathrm{~b} & 6.75 \mathrm{~b} & 836 & 2.33 \mathrm{a} & 21.2 \mathrm{~b} & 70 \mathrm{a} & 2.7 \mathrm{~b} & 57.0 \\ \text { Spur } & 23.4 \mathrm{a} & 8.84 \mathrm{a} & 754 & 1.73 \mathrm{~b} & 43.8 \mathrm{a} & 64 \mathrm{~b} & 3.4 \mathrm{a} & 82.0\end{array}$

Lateral shoot removal (LSR)

$\begin{array}{lcccccccc}\text { Total } & 22.7 \mathrm{a} & 8.42 & 810 & 2.19 & 30.9 \mathrm{a} & 69 \mathrm{a} & 2.8 \mathrm{~b} & 65.0 \\ \text { Basal } & 22.7 \mathrm{a} & 7.65 & 840 & 1.81 & 27 \mathrm{a} & 66 \mathrm{a} & 2.7 \mathrm{~b} & 58.0 \\ \text { Without } & 21.5 \mathrm{~b} & 7.32 & 690 & 2.09 & 34.5 \mathrm{~b} & 47 \mathrm{~b} & 3.6 & 84.0 \\ \text { Interaction, LPxLSR } & \mathrm{ns} & \mathrm{ns} & \mathrm{ns} & \mathrm{ns} & \mathrm{ns} & \text { Sign. } & \mathrm{ns} & \mathrm{ns}\end{array}$

${ }^{1}$ Means followed by the same letters are no significantly different according to Tukey's test $(p \leq 0.05)$. Interactions were Sign. $=p \leq 0.05$, and ns $=$ not significant $\mathrm{p}>0.05$.

tionship between the Ravaz index (fruit weight/ cane weight) and the leaf area/fruit weight ratio. All vines evaluated in experiments 1,2 and 3 were placed into four groups; 1 ) without cluster thinning (12 vines without cluster thinning in experiment 1), 2) standard canopy management (54 vines for experiments 1, 2 and 3), 3) spur pruning (18 vines spur pruned in experiment 3 ) and 4 ) cluster thinning with low vigor (6 vines in experiment 1). 
Table 2. Effects of cluster thinning and pruning weight combinations on the yield, ripeness and vine balance in Carmenérè grapevines.

\begin{tabular}{|c|c|c|c|c|c|c|}
\hline Treatments & $\begin{array}{l}\text { Yield } \\
\text { g vine }^{-1}\end{array}$ & $\begin{array}{l}\text { Soluble solids } \\
{ }^{\circ} \text { Brix }\end{array}$ & $\begin{array}{l}\text { Skin phenols } \\
\mathrm{mg} \mathrm{L}^{-1}\end{array}$ & $\begin{array}{l}\text { Extractable } \\
\text { anthocyanins } \\
\mathrm{mg} \mathrm{L}^{-1}\end{array}$ & $\begin{array}{l}\text { Inside } \\
\text { Cluster } \\
\% \\
\end{array}$ & $\begin{array}{l}\text { Leaf area/crop } \\
\text { weight }\end{array}$ \\
\hline \multicolumn{7}{|c|}{ Low pruning weight $-50 \%$} \\
\hline cluster thinning & $2,440 \mathrm{~b}^{1}$ & $24.4 \mathrm{a}^{1}$ & $19.8 \mathrm{a}^{1}$ & $866.3 \mathrm{a}$ & $4.77 b^{1}$ & $16.4 \mathrm{bc}^{1}$ \\
\hline \multicolumn{7}{|c|}{ Low pruning weight $-0 \%$} \\
\hline cluster thinning & $4,230 \mathrm{ab}$ & $22.4 \mathrm{~b}$ & $14.9 \mathrm{~b}$ & $647.0 \mathrm{~b}$ & $45.83 \mathrm{ab}$ & $9.03 \mathrm{c}$ \\
\hline \multicolumn{7}{|c|}{ Middle pruning weight - $50 \%$} \\
\hline cluster thinning & $2,788 \mathrm{~b}$ & $21.1 \mathrm{bc}$ & $17.2 \mathrm{ab}$ & $753.7 \mathrm{ab}$ & $60.00 \mathrm{a}$ & $17.5 \mathrm{~b}$ \\
\hline \multicolumn{7}{|c|}{ Middle pruning weight $-0 \%$} \\
\hline cluster thinning & 4,839 a & $21.7 \mathrm{bc}$ & $14.5 \mathrm{~b}$ & $637.7 \mathrm{~b}$ & $48.80 \mathrm{a}$ & 9.9 bc \\
\hline \multicolumn{7}{|c|}{ High pruning weight $-50 \%$} \\
\hline cluster thinning & $4,089 \mathrm{ab}$ & $21.9 \mathrm{bc}$ & $14.7 \mathrm{~b}$ & $642.3 \mathrm{~b}$ & $38.00 \mathrm{ab}$ & $26.5 \mathrm{a}$ \\
\hline \multicolumn{7}{|c|}{ High pruning weight $-0 \%$ cluster } \\
\hline thinning & $5,859 \mathrm{a}$ & $20.9 \mathrm{c}$ & $19.9 \mathrm{a}$ & $871.7 \mathrm{a}$ & $67.93 \mathrm{a}$ & $15.3 \mathrm{bc}$ \\
\hline
\end{tabular}

${ }^{1}$ Means followed by the same letters are no significantly different according to Tukey's test $(\mathrm{p} \leq 0.05)$.

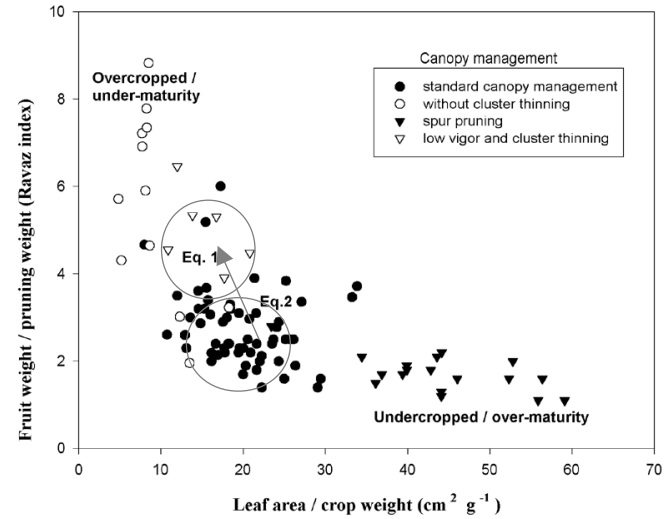

Figure 1. Relationship between crop weight/pruning weight ratios with leaf area/crop weight ratios in Carménère vines under different management conditions.

Eq. 1= Equilibrium or balance 1 .

Eq. $2=$ Equilibrium 2 or balance 2 .

The lower circle (Equilibrium 2, Figure 1) represents a reasonable vine balance not related to the best fruit composition at this harvest date. For vineyards cultivated in high growth potential sites, it is difficult to obtain low vigor even with strong canopy management due to high vigor and late ripeness of Carménère grapevines (Gil and Pszczolkowski, 2007). This vine balance level was higher than $14 \mathrm{~cm}^{2} \mathrm{~g}^{-1}$ (approximately $20 \mathrm{~cm}^{2} \mathrm{~g}^{-1}$ ) and presented a Ravaz index lower than 5 (approximately 2.5). The harvest must be delayed for these grapevines to wait for better fruit compositions, because the improvement of microclimate conditions did not improve the grape ripeness (Table 2). Hunter (2000) suggested that leaf removal and lateral shoot thinning do not necessarily modify accumulation of soluble solids in grapevines. In Figure 1 , these vines are named as standard canopy management, including 12 vines cluster thinned with high and middle vigor in experiment 1, 24 vines in experiment 2 and 18 vines cane pruned in experiment 3 .

The spur pruning vines caused lower yield and worse canopy characteristics $(100 \%$ more leaf area/fruit weight ratios, lower Ravaz index levels, higher leaf layer numbers and lower vineyard scorecards) than cane pruning (Table 1). However, these grapes had high soluble solids (Figure 2). This vicious circle of vegetative growth, as noted by Smart and Robinson (1991) is because this kind of pruning is not recommended for Carménère vines (Gil and Pszczolkowski, 2007). Theses vines were under cropped and are shown as black triangles in Figure 1. 


\section{Low vigor with high and low} crop load
Middle vigor with spur and cane pruning

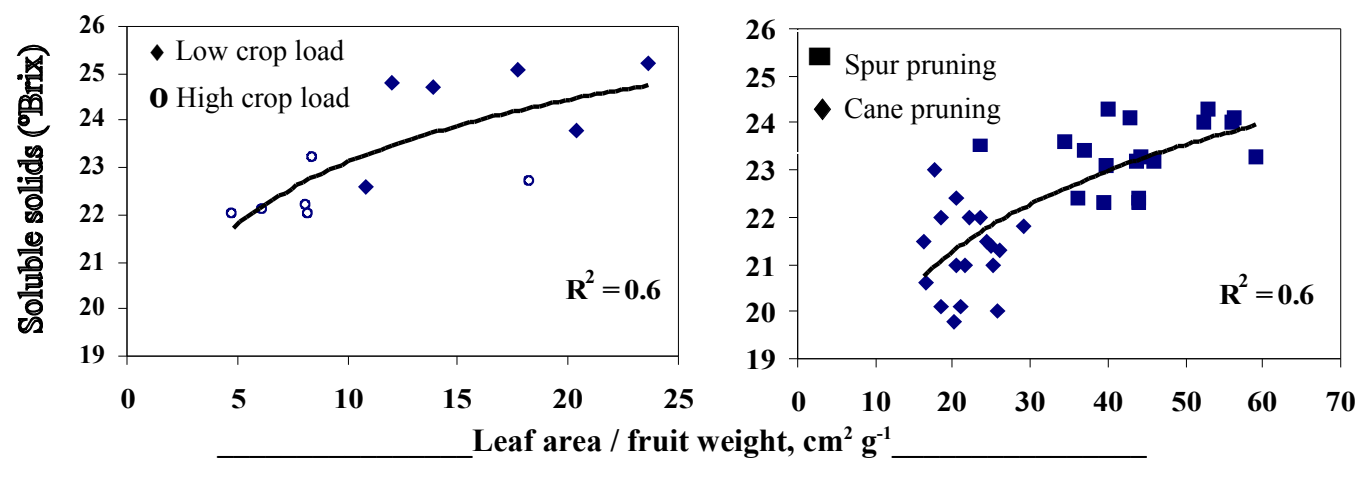

Figure 2. The regression between soluble solids and leaf area/crop weight ratios in Carménère grapevines at harvest is shown. The comparison between low vigor with low and high crop load and middle vigor with spur and cane pruning is shown.

Values found at the top of the figure (blank circles without cluster thinning vines) represent an imbalance of over cropping, and these grapevines obtained low soluble solids. However, their vine balance ranged from 6.5 to 12.5 $\mathrm{cm}^{2} \mathrm{~g}^{-1}$ with a Ravaz index ranging between 5 and 10, which was an appropriate vine balance according to Kliewer and Dokoozlian (2005). Nevertheless, Howell (2001) suggested that cool climate and late wine cultivars, such as Carménère, have higher physiological requirements and, hence, need larger leaf area/crop weight ratios than these levels.

\section{Within vine balance}

Table 1 shows that a low vigor produced a higher Ravaz index, lower leaf area/crop weight ratio, better vineyard scorecard and the lowest inside cluster percentage. All of these indexes are positively related to high quality wines according to Smart and Robinson (1991).

The blank triangles inside the circle in the top of the graph (Equilibrium 1, Figure 1) represent the optimal vine balance when considering the grape ripeness. These vines had low vigor and low crop load, and their vine balance level $\left(16.4 \mathrm{~cm}^{2} \mathrm{~g}^{-1}\right)$ was on the higher end of balance levels as proposed by Howell (2001). The statistical analyses to determine the effect of vigor and crop load on yield, ripeness and vine balance are shown in Table 2. The low vigor and low crop load vines as well as the high vigor and high crop load treatments achieved better levels of extractable anthocyanins, percentage of skin phenols and levels of soluble solids. This improved phenolic performance has been found with cluster thinning (Matus et al., 2006) and low vigor vines (Cortell et al., 2006). High levels of chemical and phenolic ripeness, higher sun exposure of clusters and acceptable leaf area/crop weight ratios were only achieved in low vigor and $50 \%$ cluster vines. Winkler (1958) proposed to determine the vine balance according to the accumulation of soluble solids. In this study, there were two regression analyses $\left(\mathrm{R}^{2}=0.6\right)$ to demonstrate the relationships between soluble solid levels ( ${ }^{\circ}$ Brix) and leaf area $\left(\mathrm{cm}^{2} \mathrm{~g}^{-1}\right.$; Figure 2). The leaf graph of low vigor treatments indicated a requirement for approximately $22 \mathrm{~cm}^{2}$ of leaf area per gram of fruit to achieve $24^{\circ} \mathrm{Bx}$ and that was only reached by the low vigor and $50 \%$ cluster thinning treatment. 
The graph on the right depicting pruning length indicated that spur pruned vines required 55 $\mathrm{cm}^{2}$ to reach $24^{\circ}$ Brix. Although both graphs depicted a high sugar level attainment, only the left graph indicates vine balance because the right graph indicated over cropping.

\section{Harvest time}

As shown in Table 2, the maturity advances with spur pruning, low vigor (coinciding with Bledsoe et al., 1988) and cluster thinning (coinciding with Matus et al., 2006). In contrast, maturity is delayed with high vigor, higher crop yield and cane pruning. All vines will probably reach ripeness on the time. However, winemakers of Chilean Carménère must deal with the following two situations: harvesting late may cause the development of fungal diseases (Pszczolkowski et al., 2001) and may decrease the levels of free amino nitrogen (Bor- deau, 2000) or harvesting early produces high content of herbal aromas and seed tannins in grapes (Gil and Pszczolkowski, 2007; Belancic and Agosin, 2007). This study proposes several management practices for modifying the time of harvest and improving the fruit composition in Carménère grapevines.

In conclusion, an early maturity was reached with spur pruning, low vigor and cluster thinning in these growing conditions. Furthermore, the appropriate vine balance was only obtained in vines with low vigor and cluster thinning. A vine balance that was approximately $16 \mathrm{~cm}^{2}$ $\mathrm{g}^{-1}$ of leaf area per crop weight produced better grape compositions at harvest. The vine balance of Carménère grapevines constantly demonstrated higher levels than the levels reported in literature. An early sugar maturity was reached with spur pruning, low vigor and cluster thinning with a low crop load. However, an early phenolic maturity was only obtained in vines with low vigor and cluster thinning.

\section{Resumen}

C. Fredes, Y. Moreno, S. Ortega y E. Von Bennewitz. 2010. Balance del viñedo: un estudio de caso en un viñedo Carménère. Cien. Inv. Agr. 37(1):143-150. Vitis vinifera cv. Carménère es una variedad vigorosa que requiere alta acumulación de temperaturas y luminosidad para lograr una óptima madurez fenólica y disminuir sus aromas herbáceos lo cual ha implicado retrasar significativamente su fecha de cosecha en Chile. Esta investigación se desarrolló bajo la hipótesis que el manejo de follaje, el vigor y la carga podrían modificar las relaciones vegetativo-productivas para adelantar o atrasar su madurez y conseguir el balance de viñedo. El objetivo de este estudio fue determinar el balance del viñedo y momento de madurez en viñedos Carménère. Se evaluaron diferentes niveles de vigor, poda y manejo de follaje. El estudio se llevó a cabo en el Valle Central de Chile en vides a pie franco, conducidas con cuatro cargadores, en espaldera simple vertical, localizada en suelos de alto potencial de crecimiento. La madurez pudo atrasarse con alto vigor y alta carga. Bajo estas condiciones se alcanzó una madurez temprana utilizando poda en pitones, bajo vigor y recurriendo también al raleo de racimos. Un adecuado balance de viñedo fue obtenido a partir de vides por bajo vigor y baja carga. Mediante un método gráfico es mostrado el balance de Carménère bajo estas condiciones de manejo.

Palabras claves: Balance del viñedo, deshoje, madurez de uva, poda, raleo de racimos, Vitis vinifera. 


\section{References}

Belancic, A., and E. Agosin. 2007. Methoxypyrazines in grapes and wines of Vitis vinifera cv. Carménère. Am. J. Enol Vitic. 58:462-469.

Bledsoe, A., W. Kliewer, and J. Marois. 1988. Effects of timing and severity of leaf removal on yield and fruit composition of sauvignon blanc grapevines. Am. J. Enol Vitic. 39:49-54.

Bordeu, E. 2000. Niveles de nitrógeno fácilmente asimilable. Agronomía y Forestal UC (Chile) 3: 4-7.

Cortell, J., M. Halbleib, A. Gallagher, T. Righetti, and J. Kennedy. 2006. Influencia del vigor de la uva (Vitis vinifera cv. Pinot noir) sobre las protoantocinidinas del vino. Primera parte. Revista Enología 12:30-33.

Edson, C.E., G.S. Howell, and J.A. Flore. 1995. Influence of crop load on photosynthesis and dry matter partitioning of Seyval blanc grapevines. III. Seasonal changes in dry matter partitioning, vine morphology, yield, and fruit composition. Am. J. Enol. Vitic. 46:478-485.

Fredes, C. 2007. Vine balance of Vitis vinifera cv. Carménère on high growth potential sites. Tesis de Magister en Horticultura, Universidad de Talca, Chile, $20 \mathrm{p}$.

Gil, G., and P. Pszczolkowski. 2007. Viticultura, Fundamentos para Optimizar Producción y Calidad. Ediciones Universidad Católica de Chile. Santiago, Chile. 535 p.

Howell, G.S. 2001. Sustainable grape productivity and the growth-yield relationship: a review. Am. J. Enol. Vitic. 52:165-174.

Hunter, J.J. 2000. Implications of seasonal canopy management and growth compensation in grapevine. S. Afric. J. Enol. Vitic. 21:81-91.

Hunter, J.J., and E. Archer. 2001. Long-term cultivation strategies to improve grape quality. VIII Congreso Latino Americano de Viticultura y Enología. Montevideo, Uruguay.

Intrieri, C, S. Poni, G. Lia, and M. Gómez del Campo. 2001. Vine performance and leaf physiology of conventionally and minimally pruned Sangiovesse grapevines. Vitis 40(3): 123-130.

Kliewer, M., and N. Dokoozlian. 2005. Leaf area/ crop weight ratios of grapevines: influence on fruit composition and wine quality. Am. J. Enol Vitic. 56:170-181.

Kliewer, M., and R. Weaber. 1971. Effect of crop level and leaf area on growth, composition and coloration of Tokay grapes. Am. J. Enol. Vitic. 22:172-177.

Mattivi, F., U. Vrhovsek, D. Masuero, and D. Trainotti. 2009. Differences in the amount and structure of extractable skin and seed tannins amongst red grape varieties. Aust. J. Grape Wine Res. 15:27-35

Matus, M., J. Rodriguez, and M. Ocvirk. 2006. Cluster thinning on Vitis vinifera cv. Malbec. Effect on yield components and berry phenolic composition. Revista de la Facultad de Ciencias Agrarias, Universidad Nacional de Cuyo 38:105-112.

Pszczolkowski, Ph., B.A. Latorre, and C. Ceppi Di Lecco. 2001. Efectos de los mohos presentes en uvas cosechadas tardíamente sobre la calidad de los mostos y vinos cabernet Sauvignon. Cien. Inv. Agr. 28:157-163.

Saint-Cricq, N. N. Vivas, and Y. Glories. 1998. Madurité phénolique. Definition et contrôle. Revue Francaise d'Oenologie 173:22-25.

Smart, R. 1985. Principles of grapevine canopy microclimate manipulation with implications for yield and quality. A review. Am. J. Vitic. Enol. 36:230-239.

Smart, R., and M. Robinson. 1991. Sun light into wine; A handbook for winegrape canopy management. Ed. Winetitles. Adelaide, Australia. 72 pp.

Tassie, E. and Freeman, B. 1992. Pruning. In: B.G. Coombe and P.R. Dry (eds.). Viticulture. Volumen 2 Practices. Winetitles, Adelaide. Australia. P. 66-84.

Van Schalkwyk, D., J.J. Hunter, and J.J. Venter. 1995. Effect of bunch removal on grape composition and wine quality of Vitis vinifera L, cv. Chardonnay. S. Afric. J. Enol. Vitic. 19:15-25.

Vasconcelos, C., and S. Castagnoli. 2000. Leaf structure and wine performance. Am. J. Vitic. Enol. 51(4):390-396.

Winkler A. 1958. The relation of leaf area and climate to vione performance and grape quality. Am. J. Enol Vitic. 9:10-23.

Zoecklein, B., F. Kenneth, B. Gump, and F. Nury. 2001. Análisis y producción de vino. Editorial Acribia, Zaragoza, España. 613 p. 